\title{
Professionalism and personal integrity: a humble example in a humble fisherman
}

\author{
Maria Fransisca Andanti ${ }^{*}$
}

${ }^{1}$ Buddhist Education, Smaratungga Buddhist College, Boyolali, Indonesia

\section{ABSTRACT}

The paper addresses professionalism and personal integrity, what lies between them, how they connect each other, and what real example could be drawn into both issues. It discusses professionalism and personal integrity as proposed by Suseno (1991). It also highlights professionalism from Buddhist perspective. Finally, it analyzes professionalism and personal integrity in the character of Santiago, Hemingway's The Old Man and the Sea (1952) as proposed by Khan (2014). The paper concludes that professionalism is not only about mastering certain skills and having certain knowledge, but it should be built based on personal integrity.

\section{ARTICLE INFO}

Keywords:

professionalism; personal integrity; character

\section{Article History:}

Received: May $10^{\text {th }}, 2021$

Revised: June $25^{\text {th }}, 2021$

Accepted: June $26^{\text {th }}, 2021$

Published: June 28th 2021

How to Cite in APA Style:
Andanti, M. F. (2021).
Professionalism and personal
integrity: a humble example
in a humble fisherman.
Smaratungga: Journal of
Education and Buddhist
Studies, 1(1), 67-75.

\section{Introduction}

Professionalism has been being a magic word when people drag themselves into the formal aspects of their lives. It is usually important in all service-providing professions (Zafiropoulus, 2017). Being said professional means that a person is successful in achieving certain standard. Yet, professionalism does not only evolve on skills acquired by certain individuals, moreover, it is also about values (Vivanco and Delgado-Bolton, 2016). Therefore, being professional means behaving like one since he/she believes in several principles that motivate individuals into acting out them.

It is strongly possible, then, to relate professionalism with integrity. Although it may vary on individuals, integrity is more than ethics in individual level, yet it is more about "the characters of individual that are consistently considerate, compassionate, transparent, honest, and ethical" (Duggar, 2009). In one of the attempts to define integrity, Huberts (2018) cited what Montefiore \& Vines $(1999,9)$ concluded that integrity is "wholeness or completeness, as consistency and coherence of principles and values". Having integrity, then, is like

\footnotetext{
*Corresponding author: fransisca.andanti@gmail.com

Published by Center of Research and Publication of Smaratungga Buddhist College

This is an open access article under the CC BY-NC 4.0

(https://creativecommons.org/licenses/by-nc/4.0/)
} 
being professional when individual should not only hold their beliefs but also act them out.

Several researches have shown how professionalism and integrity worked as two inseparable and collaborative units that contributed in professional life positively. Banks (2010) concluded that having professional integrity means being morally good/having right conduct, standing for something, and having a capacity/moral competence. Another study conducted by DuBois, Chibnall, Tait, \& Vander Wal (2018) attempted at improving researchers' professionalism and integrity by providing remediation training addressing the root causes of violations of rules and regulations in research.

However, where does professionalism come from? And, does professionalism always deal with the formal world? This paper is going to explore how professionalism and personal integrity are strongly connected and how it exists not only in the formal world. It uses Suseno's (1991) concept of Professionalism and Personal Integrity and explores professionalism and integrity from Buddhist perspective. The paper then highlights the professionalism of Santiago, a humble fisherman in Hemingway's The Old Man and The Sea as proposed by Khan (2014). It then analyzes the highlight from professionalism and personal integrity as proposed by Suseno (1991) and how Buddhism views professionalism and integrity.

\section{Method}

This research employed library study. It started with reviewing Suseno's Professionalism and Moral, Intellectual, and Religious Integrity. Then, it reviewed Buddhist perspective about professionalism. Next, the paper reviewed Khan's analysis in Santiago in Hemingway's The Old Man and the Sea. Finally, the paper reviewed and discussed Santiago as a humble example of two strong traits, professionalism and personal integrity

\section{Findings}

\section{Professionalism and moral, intellectual, and religious integrity}

Suseno (1991) described professionalism as an ideal word that young people always dream about in this modern era. He revealed that many students give up their dreams in their college for years as society reformer, national conscience, and another dream to be a professional. Being a professional, then, is related with certain skill. Moreover, Suseno (1991) emphasized that being a professional means also being a pragmatist. A professional must have unwavering belief to do their job without being influenced by religious view and their own ideology and without being distracted by their family relationship and personal problems.

However, Suseno (1991) pointed out the gap between myth and reality when dealing with professionalism. People want to be professional and they need professionals. Unfortunately, they are far from the reality since they question their own professionalism inside themselves.

In fact, life does need professionals to achieve certain progress. Suseno (1991) believed that professionalism lies in somebody's characteristic structure wholly. To be a professional, someone needs training and learning. To be a 
professional, even, is more than to be an expert in a certain field. A professional has a working quality that is more than just an expertise. Therefore, professionalism can be achieved by personal integrity and personal integrity is built from intellectual, moral, and religious integrity (Suseno, 1991).

\section{Professionalism and personal integrity}

Suseno (1991) defined integrity as somebody's whole and pure personality that does not change in every life dynamics, relationships, or activities. It means that a person has perseverance to be him/herself. He/she does not become somebody else. They are also honest people. They are not afraid of knowing their conscience orientation. They are not tempted to be bought by corruption. They are independent and others can rely on their words. Suseno (1991) argued that becoming professional is impossible to be done without having personal integrity since a professional should have personal persistence so that they are able to face various situation. The personal integrity, finally, can be achieved through intellectual, moral, and religious integrity.

\section{Intellectual integrity}

The typical of intellectual integrity is involvement to truth (Suseno, 1991). It is shown in somebody's attitude and feeling towards dishonesty. For example, a student will not only refuse to steal others' idea in his/her thesis, but he/she will also feel disgusted by intellectual dishonesty.

Besides, a person with intellectual integrity always seeks for truth. He/she will always want to know the cause of a problem. They are also open to critiques and love discussing things. Even, Suseno (1991) reasoned that a professional is not supposed to change a debate with a dialogue since a truth should be found out completely. If a sharp discussion and opinion conflict are turned into peace talking, then we have conducted mental corruption. A professional, moreover, is not afraid of admitting that he/she does not know something and did a mistake.

Suseno (1951) claimed that without involving to truth, it is impossible to be a professional. A professional must be able to solve problems properly. $\mathrm{He} / \mathrm{she}$ does not only finish certain job, but they should be able to work independently and be independently intellectual.

\section{Moral integrity}

The moral integrity proposed by Suseno (1991) is not moral in general. A professional possibly has various morality at home, at office, or in different things in his/her life. In fact, without high personal moral, somebody is not able to be a capable professional.

However, Suseno (1991) mentioned some characteristics of moral integrity in a professional. They include: not playing dirty, not betraying friends, being honest, not even thinking about terrible deception, but thinking that integer is not hypocrite, not being mean, being humble, not being boastful and not making improper impression, not running away from their responsibility and standing behind their mistakes, being determined to give what is been expected from them, 
loving quality, and finishing their job based on the standard even if they are not being controlled.

Those characteristics, according to Suseno (1991), clearly described how moral and intellectual integrity are related. A professional will not have maturity without moral integrity. Moral integrity is needed to face critical condition that is more than just an expertise.

\section{Religious integrity}

Most people in this modern life think that professionalism does not relate with religiosity values (Suseno, 1951). People cannot bring religion into business talking or social relationship. Yet, materialistic-based views are no longer irrelevant since materialistic development is considered inadequate so that people need to have certain belief.

In the professional world, according to Suseno (1991), it is more proper to talk about religious integrity, other than religiosity in general. Religious integrity is somebody's basic belief. A professional, then, should do something based on his/her own basic belief. Suseno (1991) said that a professional will not park his/her belief outside. Besides, religious integrity also means giving freedom to others and not using power to increase his/her own religious belief. Therefore, religious integrity is strongly related with intellectual and moral integrity. Morally, religious integrity can be achieved if somebody has humbleness in religion. Somebody also needs to have intellectual integrity to have basic belief.

\section{Professionalism in Buddhist perspectives}

In Buddhism, professionalism (sippa) is an early step to reach success in working. In the Ganakamoggallãna Sutta of Majjhima Nikãya, the Buddha said, "Come, bhikkhu, be virtuous, restrained with the restraint of Pātimokkha, be perfect in conduct and resort, and seeing fear in the slightest fault, train by undertaking the training percepts" (M.III.1). It means that when practicing Dharma or working, somebody should work correctly based on the rules agreed upon. The Buddha also explained how people should behave when they are on work so that they can minimize mistakes that lead to organization setback as what he said, "...On seeing a form with the eye, do not grasp at its signs and features. Since, if you were to leave the eye faculty unguarded, evil wholesomeness states of covetousness and grief might invade you, practice the way of its restraint, guard the eye faculty, undertake the restraint of the eye faculty..." (M.III.2). It is important, then, for somebody to have self-control so that they can avoid bad behavior and work well.

Besides, it is also important to have full awareness towards whatever is happening, even it is a very small thing in work to ensure organization success, just like when a bhikkhu is attaining enlightenment. "Come, bhikkhu, be possessed of mindfulness and full awareness. Act in full awareness when going forward and returning; act in full awareness when looking ahead and looking away; act in full awareness when flexing and extending your limbs...act in full awareness when walking, standing, sitting, falling asleep, waking up, talking, and keeping silent" (M.III.2-3). 
It is always not easy to develop an organization well since there will be many problems ahead, just like the Sangha have. The Buddha, in the Sãmagãma Sutta of Majjhima Nikãya, mentioned the four litigations that might be faced in an organization. "Ānanda, there are these four of litigation. What four? Litigation because of a dispute, litigation because of an accusation, litigation because of an offence, and litigation concerning proceedings" (M.II.247). The litigations can be settled by seven ways as the Buddha said, "Ānanda, there are these seven kinds of settlement of litigation. For the settlement and pacification of litigations whenever they arise: removal of litigation by confrontation may be provided, removal of litigation on account of memory may be provided, removal of litigation on past insanity may be provided, the effecting of the acknowledgement of an offence, the opinion of the majority, the pronouncement of bad character against someone, and covering over with grass" (M.III.247).

In the Mahãdhammasamãdãna Sutta of Majjhima Nikãya, the Buddha explained how to undertake things, "...There is a way of undertaking things that is painful now and ripens in the future as pain. There is a way of undertaking things that is pleasant now and ripens in the future as pain. There is a way of undertaking things that is painful now and ripens in the future as pleasure. There is a way of undertaking things that is pleasant now and ripens in the future as pleasure" (M.I.310-11). When working, somebody who acts professionally should be wise, not practice and do things that will not bring any success in future, although they are easy and fun to do. On the contrary, a wise man will practice and do things that will bring success, although they are exhausting, since a wise man can see things clearly and in full awareness. As the Buddha said, "...one who is wise, knowing this way of undertaking things that is painful now and ripens in the future as pleasure, understands it as it actually is thus...Knowing it, understanding it as it actually is, the wise one does not avoid it but cultivates it..." (M.I.311). It means that somebody should hold on to the true morality to do everything based on what is good.

\section{Professionalism in the old man and the sea}

The Old Man and the Sea was Ernest Hemingway's masterpiece novel published in 1952 that brought him into the Pulitzer Awards a year later. It tells a story about Santiago, and old Cuban fisherman who struggles with failure, barriers, and challenges when fishing for days. He had spent eight four days fishing without having any fish yet. Santiago then decided to go far into the ocean.

A giant marlin took his bait, but he was not able to reel it and the marlin pulled him and his small boat. For three days, Santiago and the marlin were fighting and waiting who was stronger and who would give up between the two of them. Santiago almost fainted of exhaustion, but he managed to shoot the giant marlin right on its heart as it was getting weaker.

He then sailed home with the marlin tied to his small boat. But, the giant marlin's blood track invited many sharks in the sea and they attacked Santiago. With his remained strength and power, Santiago fought the sharks and went home, bringing only the giant marlin's skeletal carcass. Eventually, Santiago's friends, his fellow fishermen paid their respect and appreciation to Santiago, the thing they had left long ago. And, Manolin, a young boy who once decided not to go fishing with Santiago, begged to take him in Santiago's next fishing. 
This paper is going elaborate that a humble and old fisherman could possess such quality of professionalism, as well as personal integration as proposed by Suseno (1991) and the Buddhist perspective mentioned above. Khan (2014) mentioned the eight sides of Santiago's professionalism. They are positivism, human nature relationship, great regards for profession, boldness, fortitude, sanguinity, firmness, and stimulation.

\section{Positivism}

Positivism or always thinking and acting positively towards all things was shown in how Santiago faced one of the crucial times in his battle with the giant marlin, isolation. He was all alone in the ocean with his hands clutching on his fishing rod. He only ate the tunas once he planned as his baits for three days. His left hand was hurt and cramped. His right hand was also scratched. Yet, he did not lose any hope, nor he did underestimate his rival, the marlin. Khan (2014, p. 558) presented what Santiago said in the novel to highlight his positivism, "But, thank God, [the fish] are not as intelligent as we who kill them; although they are more noble and more able."

Khan (2014) argued Santiago's positivism was strongly represented in isolation and self-belief. Becoming isolated in the ocean, he trusted his own efforts and luck. It was shown in what he said alone in the ocean, "Every day is a new day. It is better to be lucky. But I would rather be exact. Then, when luck comes you are ready" (Khan, 2014).

Besides, Santiago's positivism was also shown in how he trusted himself. Khan (2014) mentioned that there was certain quality characterized one person from another in professionalism. They included will, ability, and perseverance. That is why Santiago trusted himself, more than any luck.

\section{Human nature relationship}

Being a fisherman since he was young, Santiago was also close to the ocean world. According to Khan (201), Santiago possessed a unique nature-connection. In the first day he went into the ocean with his small boat, he talked to the ocean as if he talked with a woman. During his isolation in the ocean he even considered the birds as his friends. He saw the sharks attacking him as personal rivals. He talked to turtles, jellyfishes, fishes, and birds and tested how they interacted with each other.

\section{Great regards for profession}

As mentioned above, Santiago was a fisherman since he was young. He loved his job to bits. Khan (2014) thought that even when he had been in a bad situation, he still loved his job. Santiago remembered that being a fisherman was the one thing he wanted to do since he was born. It was shown in what Hemingway wrote, "Perhaps, I should not have been a fisherman, he thought. But that was the thing that I was born for" (Khan, 2014).

Although staying in the middle of the ocean and starting to get frustrated, Santiago still respected his profession and stood behind the wholeness of his profession. He mentioned of the basic foundations of catching fish was pride. A 
fisherman loves his fish and he should kill them. It was shown in this excerpt, "You did not kill the fish only to keep alive and to sell for food, he thought. You killed him for pride and because you are a fisherman. You loved him when he was alive, and you loved him after. If you love him, it is not a sin to kill him" (Khan, 201).

\section{Boldness}

Khan (2014) said that boldness becomes one of the qualities Santiago possesses as a professional. A huge marlin is "the symbol of the mysterious world of the anonymous challenges everyone" (Khan, 2014). Santigao was dragged by the marlin and he did not know any of it. He did not know what kind of fish he was facing and how the fish looked like. He just imagined its power, size, and determination.

Besides, during his three-day fight with the marlin, Santiago did not ever think about giving up. He kept holding on and faced his isolation and battle bravely. He believed that somebody must do everything he can do well, no matter what happens with them. This excerpt proves Santiago's bravery, "But man is not made for defeat...A man can be destroyed but not defeated" (Khan, 2014).

\section{Fortitude}

Santiago does not only possess bravery, but also remarkable fortitude. Khan (2014) praised him for not being frustrated or tired of doing his job, fishing. In fact, Santiago had to go through a lot of misery when fighting the giant marlin. He stood steadfast and insisted not letting the marlin go although he felt tired, his left hand was cramped, and his right hand was hurt. What Santiago said to the fish proved his fortitude, "Fish, he said softly, aloud, "I'll stay with you until I am dead" (Khan, 2014).

\section{Sanguinity}

Khan (2014) described Santiago's optimism during his battle with the giant marlin in the vast ocean in how Santiago himself believed that he would not go home without bringing the marlin. In his fatigue battling with the marlin, he still dreamt about white-sand beach and the fish. He was still cheerful and believed that he could win his battle. It was shown in what Santiago said, "I have never seen or heard of such a fish. But I must kill him. I am glad we do not have to try to kill the stars" (Khan, 2014).

\section{Firmness}

Although Santiago kept positive, optimist, and cheerful attitude during his isolation in the vast ocean with the giant marlin, Khan (2014) found his firmness in facing the more dangerous situation, which was fighting with the sharks that wanted his marlin. After getting exhausted of fighting with the marlin for three days, Santiago did not lose his firmness and was still brave facing the sharks with his remained energy. He understood that there would be more sharks coming and knew well how to face them. Even, when the day was getting darker, he still said, "I'll fight them until I die" (Khan, 2014). 


\section{Stimulation}

Khan (2014) said that inspiration can lead to success in professional life. In the Old Man and the Sea, Santiago was inspired by DiMaggio, a handicapped baseball player. During his isolation in the vast ocean and battling with the giant marlin, Santiago remembered DiMaggio and took him as his strength source to keep holding on. It was shown in what Santiago said, "Have faith in the Yankees my son. Think of the great DiMaggio" (Khan, 2014).

Besides, Santiago also remembered his youth as a strong and skillful fisherman. As an old fisherman he was now, he still believed that he still had such qualification. Therefore, he was sure that he would still bring the marlin back. Although he only brought the giant marlin's skeletal carcass, Santiago did not let the sharks beat him and take the whole marlin with them.

The eight Santiago's professionalism traits mentioned by Khan (2014) are in line with what Buddhism views about professionalism. Santiago's high-leveled of skills and knowledge in his persistence to wait for the marlin to get weaker and bravery to fight the sharks shows that it is important to work based on the rules as the Buddha implied in the Ganakamoggallãna Sutta of Majjhima Nikãya. Santiago's positivism, sanguinity, and regards for his profession also proves how he controlled the situation in the field as the Buddha said that is important to have self-control in the working world as mentioned in that sutta.

The needs of full awareness in Santiago's firmness, boldness, and fortitude when fighting the giant marlin for three days and the sharks with his remained energy. As the Buddha said in the Mahãdhammasamãdãna Sutta of Majjhima Nikãya, that people should be wise and brave to follow the whole process when working, although it might be painful and miserable. Santiago used his whole knowledge and tough mentality to win his battle and did not run away from his enemies. He chose to finish his job and took full responsibility of his decision of going further into the vast ocean.

\section{Conclusion}

The elaboration of what happened with Santiago and how he fought during his three-day fishing in the vast ocean shows that being a professional certainly needs certain skills and knowledge to achieve certain standard. However, being a professional is more than just being an expert in certain field. It, even, needs more high-leveled personal constancy and maturity. Such quality is formed of intellectual, moral, and religious integrity that creates personal integrity. Personal integrity enables people to act based on certain values and principles.

\section{References}

Banks, S.J. (2010). Integrity in professional life: Issues of conduct, commitment, and capacity. British Journal of Social Work, 40(7), 2168-2184. doi: 10.1093/bjsw/bcp152.

Bhikkhu Bodhi (Ed.). (1995). The middle length of discourses of the Buddha. Boston: Wisdom Publication. 
DuBois, J.M., Chibnall, J.T., Tait, R., \& Vander Wal, J.S. (2018). The professionalism and integrity in research program: Description and preliminary outcomes. Acad Med, 93(4), 586-592. doi: 10.1097/ACM.0000000000001804.

Duggar, J.G. (2009). The role of integrity in individual and effective corporate leadership. Ethics and Behavioral Studies, 1-7. Retrieved from: http://hdl.handle.net/20.500.12424/176503.

Huberts, L.W.J.C. (2018). Integrity: What it is and why it is important. Public Integrity, 1-15. doi: 10.1080/10999922.2018.1477404.

Khan, M.E.I. (2014). Professionalism in Ernest Hemingway's the old man and the sea. International Journal of Research (IJR), 1(9), 554-562. https://edupediapublications.org/journals/index.php/IJR/article/view/66 $5 /$.

Suseno, F. M. (1991). Berfilsafat dari konteks. Gramedia Pustaka Utama.

Vivanco, L., \& Delgado-Bolton, R. (2016). Professionalism. In H. Ten Have (Ed.), Encyclopedia of global bioethics (2312 - 2319). Springer, Cham. https://doi.org/10.1007/978-3-319-09483-0_353

Zafiropoulus, G. (2017). Definition of professionalism by different groups of health care students. Educational Research and Reviews, 12(7), 380-386. https://doi.org/10.5897/ERR2017.3132. 